\title{
Post Covid-19 Metaphoric Perceptions of Preservice Music Teachers on the Concepts of "Distance Education, Home, Graduation, University and Future"
}

\author{
Ömer Bilgehan Sonsel ${ }^{1{ }^{*}} \&$ Özlem Ömür ${ }^{2}$ \\ ${ }^{1}$ Gazi Faculty of Education, Department of Music Education, Gazi University, Turkey \\ ${ }^{2}$ Faculty of Education, Department of Music Education, Kastamonu University, Turkey \\ *Correspondence: Gazi Faculty of Education, Department of Music Education, Gazi University, Turkey. Tel: \\ 90-0533-514-6005. E-mail: sonselbilgehan@gmail.com
}

Received: July 26, 2021

Accepted: August 31, $2021 \quad$ Online Published: October 2, 2021

doi:10.5430/wje.v11n5p1

URL: https://doi.org/10.5430/wje.v11n5p1

\begin{abstract}
This study aims to reveal the perceptions of preservice music teachers on the concepts of "Distance Education, Home, Graduation, University and Future" through metaphors. The study group of the research consists of 80 preservice music teachers studying the final year of their undergraduate education at the Department of Music Education in Gazi University, Kastamonu University, Bolu Abant İzzet Baysal University, Uludağ University, Van Yüzüncüyıl University, Necmettin Erbakan University and Muğla Sitkı Koçman University as of 2020-2021 academic year. Data of the research were collected by participants completing the sentence "The concept reminds me of....because....". Collected data were analyzed with content analysis method. Participants developed 133 different metaphors; 26 related to distance education, 19 to home, 27 to graduation, 29 to university, and 32 to the concept of the future. While the metaphors they developed on the concept of distance education reflect a negative view, those about home and graduation are considered to be relatively positive. The metaphors developed on the concept of university express a longing rather than representing either a positive or a negative view. Future, on the other hand, was a concept on which preservice music teachers came up with the highest number of metaphors and all found ambiguous. Distribution of the metaphors developed by the participants and the sample sentences selected from the opinions are demonstrated under the relevant headings.
\end{abstract}

Keywords: metaphor, preservice music teacher, distance education, home, graduation, university, future

\section{Introduction}

The word "metaphor" is defined as "figurative expression, figure of speech" (TürkDilKurumu [TDK], 2021). It comes from the Greek word "Metaphora" which means to transfer and carry. "Meta" is referred to as beyond whereas "pherin" means transport. It was adapted to Turkish from French. Metaphoric structures used to describe something by analogy with something else are among the most effective examples of symbolic expression. The words "Slowly you will ascend these stairs" in the poem entitled "Stairway" by famous Turkish poet Ahmet Haşim, who is one of the pioneers of symbolism, did not actually make a suggestion about how to climb the stairs. In fact, it was a reference to the concept of life. The word "stairs", in this poem, is the metaphor of life (Tunç, 2014; p.188). Metaphor is often considered as an art of rhetoric intended to embellish discourse; however, it is much more significant than that. Making use of metaphors means a way of thinking and perceiving that permeates individuals' understanding of the world in general (Turhan \& Yaraş, 2013, p. 130).

Metaphors are frequently used in qualitative research studies, particularly in educational sciences. As in every field of education; metaphors are frequently used in the field of music education, aiming to determine the perceptions of different age groups on various concepts. For instance, in his study, Uygun (2010) focused on defining the metaphoric perceptions of preservice teachers from various fields, on traditional music genres. Tez and Uygun (2016) studied metaphoric perceptions of secondary school students on music lessons and music teachers. Babacan (2014) 
analyzed the perceptions of students at the high school of fine arts; Umuzdaş and Umuzdaş (2013) analyzed those of preservice elementary school teachers, and Akça, Şen and Kurtaslan (2019) analyzed the perceptions of music students at science and art centers regarding the concept of music through metaphors. In their studies, Sözbir and Çakmak (2016) andKoca (2012) identified the perceptions of preservice pre-school teachers regarding the concept of music through metaphors; while Eren (2018) did the same for preservice special education teachers. While Düzgören and Gerekten (2017) investigated the Anatolian High School students' metaphoric perceptions on the concept of music lessons, Girgin (2019) analyzed the perceptions of preservice music teachers on instrument education. K1liç (2017a) studied prospective music teachers' perceptions on the music education curriculum and (2017b) teacher concepts, whereas Özaydin (2019) focused on their perceptions on the concept of sound using the metaphoric analysis method.

The coronavirus first appeared in Wuhan, China in November 2019 and was declared as a worldwide pandemic by the World Health Organization (WHO) in January 2020. Due to the lethal effect of the virus called Covid-19, education activities all over the world were interrupted for a short time and then were restructured according to the course of the process. Almost $63.3 \%$ of the world's student population, which corresponds to 1,109,020 students, has been adversely affected by the pandemic. Some countries have implemented regional closures affecting millions of students (Rahiem, 2020). Higher education institutions in Turkey suspended face-to-face education as of March 16, 2020 and switched to distance education. However, this process, unlike distance education, is referred to as "Emergency Remote Teaching (ERT)". While distance education is a planned, scheduled and temporary option, emergency remote teaching is a difficult process that aims to keep education services operating in emergency situations (Bozkurt, 2020b; p. 117). Practitioners and researchers all over the world have sought to understand how to apply emergency distance education, and find ways to involve students effectively in learning at home during this incredibly difficult time (Bond, 2020). Although it was estimated to last three weeks at the beginning, emergency remote teaching process is still ongoing as of July 2021. Throughout this process, many higher education institutions either suspended or limited the admission of new students to their bachelor's degree or post-graduate programs. All teacher recruitments and assignments were cancelled. Exams and graduation ceremonies of universities; as well as the lectures, were held remotely. Although some universities wanted to switch to hybrid education, they had to limit their academic education to distance education due to the increase in the number of cases. With the advancements in distance education technology, many institutions have turned into a home internationalization model, where students were able to develop their cultural capacities without leaving home (Chan \& Nyback, 2015). Many organizations designed their own combined systems as per their organizational goals and contexts. The pandemic has changed the implementation of curriculum. This is not only due to the use of platforms and the need to consider different conditions that was not foreseen by the curriculum; but also for the reason that competencies have become a relevant context (Zamora-Antuñano et al., 2021). However, COVID-19 has hindered face-to-face and co-educational learning. Therefore, the education sector needs to re-examine and calibrate the use of technology to enable urgent distance learning among students and teachers (Toquero, 2020).

Although all the students were affected from this period to some extent, final year students were the ones to be affected the most. Even their near plans became uncertain and many exams for which they have worked very hard were suspended. Preservice teachers also suffered from a psychological breakdown throughout this process and became aimless. Many academic studies revealed that some concepts have changed for preservice teachers, particularly for those in the final year of their academic education due to the Covid-19 outbreak. In this context, a need has emerged as to reveal the post pandemic perceptions of preservice teachers on the concepts of "Distance Education, Home, Graduation, University and Future" through metaphors. In the light of all this information, this research aims to reveal the post pandemic perceptions of preservice music teachers on various concepts through metaphors. Answers to the following questions were sought within the framework of this general purpose:

1) What are the post covid-19 metaphoric perceptions of preservice music teachers on the concept of "distance education"?

2) What are the post covid-19 metaphoric perceptions of preservice music teachers on the concept of "home"?

3) What are the post covid-19 metaphoric perceptions of preservice music teachers on the concept of "graduation"?

4) What are the post covid-19 metaphoric perceptions of preservice music teachers on the concept of "university"?

5) What are the post covid-19 metaphoric perceptions of preservice music teachers on the concept of "future"? 


\section{Method}

\subsection{Research Model}

The study was based on "Phenomenology" method, which is one of the qualitative research designs, and aims to identify post covid-19 metaphoric perceptions of preservice music teachers on various concepts. "Phenomenology" is a method that focuses on evaluating an actual experience (Jasper, 1994; Miller, 2003, as cited in: Kocabıylk, 2015; p.55). It was proposed not as a philosophical system, but a method that attempts to unveil the hidden essence in certain things. In other words, it is the search for the "essences", as all questions can eventually lead you back to the problem of describing essences (Turgut, 2012; p.236). This method is basically based on suspension and bracketing (Erbaş, 1992, p.160). Phenomenology constitutes a suitable research ground for studies that aim to investigate phenomena that are not completely foreign to us but whose meaning we cannot have a full grasp of, either (Yıldırım \& Şimşek, 2008, p.72). Phenomenology is used in literature to express the facts that we are aware of but cannot comprehend and express clearly. The content analysis of the collected expressions should conceptualize the data and determine the categories that will define the phenomenon.

\subsection{Research Group}

The research group consists of 80 preservice music teachers, who are final year undergraduate students at the Department of Music Education in Gazi University, Kastamonu University, Bolu Abant İzzet Baysal University, Uludağ University, Van Yüzüncüyıl University, Necmettin Erbakan University and Muğla S1tkı Koçman University as of 2020-2021 academic year. Demographic characteristics of the group are exhibited in Table 1.

Table 1. Demographic Characteristics of the Population

\begin{tabular}{lll}
\hline Gender & $\boldsymbol{f}$ & $\boldsymbol{\%}$ \\
\hline Female & 47 & 58.8 \\
Male & 33 & 41.3 \\
Total & $\mathbf{8 0}$ & $\mathbf{1 0 0}$ \\
University of Academic Education & $\boldsymbol{f}$ & $\mathbf{\%}$ \\
Gazi University & 17 & 21.3 \\
Kastamonu University & 15 & 18.7 \\
BoluAbantİzzetBaysal University & 12 & 15 \\
Bursa Uludağ University & 11 & 13.7 \\
Van Yüzüncüyıl University & 9 & 11.3 \\
MuğlaSitkıKoçman University & 8 & 10 \\
Konya Necmettin Erbakan University & 8 & 10 \\
Total & $\mathbf{8 0}$ & $\mathbf{1 0 0}$ \\
\hline
\end{tabular}

\subsection{Collection and Analysis of Research Data}

Prior to preparing the data collection tool, previous studies that used metaphors as a tool to reveal the perceptions of preservice teachers were analyzed. It was found that some of the previous metaphor studies used the questionnaire method as a data collection tool, while semi-structured forms were used in others. Data of the research were collected with open-ended questions in order to directly reach the metaphorical perceptions of the preservice teachers on the given concepts. Data were collected using a semi-structured "preservice teacher metaphoric perception form" prepared by the researchers. The form consisted of three main parts: the first part included brief information and examples about the metaphor for preservice teachers while the second part asked the participants questions about their demographic information. In the third part, preservice teachers were asked to complete the statements "Concept1 reminds me of....because...."within the context of the given concepts. The "preservice teacher metaphoric perception form" that was developed was converted into Google Documents and sent to preservice teachers. The answers provided by the participants went through content analysis and the proposed metaphors were analyzed within the scope of the research. Metaphors produced by the participants were categorized in accordance with their content and meanings. Metaphors were further tabulated under the relevant categories, based on their frequencies. The sample preservice teacher opinion for each metaphor is indicated with the Participant no (Pno) under the relevant table. The method developed by Büyüköztürk et al. (2010, p.265), where the data are coded by both researchers was applied, in order to improve the reliability of the research. The forms obtained from the participants were coded separately by both researchers, and then compared in order to double check the consistency. 
The codes and themes were submitted for the review of two experts, and necessary revisions were made in line with their opinions. The reliability of the study was calculated by the formula suggested by Miles and Huberman (1994) where Reliability $=$ Number of Agreements / Number of Agreements + Disagreements. Inter-Rater Reliability (IRR) was found out to be $83 \%$. The codes and themes were submitted for the review of two experts, and necessary revisions were made in line with their opinions.

\section{Results}

3.1 Post Covid-19 Metaphoric Perceptions of Prospective Music Teachers Regarding the Concept of "Distance Education"

Preservice teachers developed a total of 26 metaphors on the concept of distance education and these metaphors were further gathered under 5 joint categories. Table 2 exhibits the metaphors produced by preservice music teachers on the concept of distance education under the joint categories.

Table 2. Metaphors Developed by Preservice Music Teachers on the Concept of "Distance Education"

\begin{tabular}{|c|c|}
\hline Categories & $f$ \\
\hline Distance education as a negative concept & 26 \\
\hline Torture & 10 \\
\hline Nightmare & 4 \\
\hline Persecution & 3 \\
\hline Lattice & 2 \\
\hline Incubus & 2 \\
\hline Banishment & 2 \\
\hline Hell & 1 \\
\hline Deserted Island & 1 \\
\hline Destruction & 1 \\
\hline Distance education as an abstract concept & 22 \\
\hline Air & 13 \\
\hline Quest & 5 \\
\hline Artificial Intelligence & 3 \\
\hline Placebo & 1 \\
\hline Distance education as a guiding concept & 16 \\
\hline Key & 6 \\
\hline Sun & 4 \\
\hline Path & 3 \\
\hline Compass & 3 \\
\hline Distance education as an inefficient concept & 10 \\
\hline Inequality & 4 \\
\hline Labyrinth & 2 \\
\hline Junk food & 1 \\
\hline Arid Land & 1 \\
\hline Bucket with a hole & 1 \\
\hline Customer services & 1 \\
\hline Distance education as a favorable concept & 6 \\
\hline Game & 4 \\
\hline Spice & 1 \\
\hline Angel of Fortune & 1 \\
\hline
\end{tabular}

Preservice teachers have derived 9 metaphors within the category of "distance education as a negative concept". This category bears the highest number of metaphors related to distance education. The concept "torture" was the one to be mentioned most frequently among other negative concepts. Other metaphors mentioned within this sub-category were nightmare, persecution, lattice, incubus, banishment, hell, deserted island and destruction. The fact that preservice teachers came up with such sharp and negative metaphors regarding distance education reveals that they 
did not have positive experiences about distance education process. Some of the opinions expressed by the participants under this category are as follows:

"Distance education reminds me of torture as I'm forced to do something I don't believe in." (P57);

"Distance education reminds me oflattice as I don't feel myself free in this training." (P13); "Distance education reminds me of banishment as I'm far away from school." (P24); "Distance education reminds me of a deserted island as I feel so lonely." (P21).

Preservice teachers have derived 4 metaphors within the category of "distance education as an abstract concept". The metaphors produced in this category were air, quest, artificial intelligence and placebo. Participants were observed to approach distance education with skepticism in this category. Some of the opinions expressed under this category are as follows:

"Distance education reminds me of air as I know it exists, but I can't see it." (P18); "Distance education reminds me of a quest as I feel myself empty." (P3); "Distance education reminds me of an artificial intelligence as it works well but has no soul." (P8); "Distance education reminds me of placebo as it seems useful but it's empty." (P73).

4 metaphors were expressed within the category of "distance education as a guiding concept". The metaphors in this category were key, sun, path and compass. With these metaphors, participants stated that they consider distance education as a guiding and enlightening concept. Some of the opinions under this category are as follows:

"Distance education reminds me of a key as it is an important element to unlock my professional life." (P11); "Distance education reminds me of sun as it's the only thing that gives me hope in such a hopeless process." (P52); "Distance education reminds me of a path as it's the only way through which I can achieve the professional life I want." (P36); "Distance education reminds me of a compass as it guides us when we, as the whole world, have lost our way." (P14).

Preservice teachers came up with6 metaphors within the category of "distance education as an inefficient concept". These metaphors were inequality, labyrinth, junk food, bucket with a hole and customer services. Definition of distance education with these metaphors revealed that their expectations were not met in terms of the quality of education. Some of the sample views on related metaphors are as follows:

"Distance education reminds me of inequality as it is a one-man achievement." (P28); "Distance education reminds me of a labyrinth as we're just bouncing around in the system." (P38); "Distance education reminds me of junk food as it just rots teeth although it looks delicious." (P2); "Distance education reminds me of customer services as I never get a result." (P7).

Last category within the context of metaphors asked to preservice music teachers with respect to distance education was "distance education as a favorable concept". Prospective teachers produced 3 metaphors under this category as game, spice and angel of fortune. Some of the sample opinions expressed by prospective teachers with respect to metaphors are as follows:

"Distance education reminds me of a game as it becomes a lot of fun when you learn the rules." (P78);

"Distance education reminds me of spice as it sounded pretty tasty after the boring university environment." (P1); "Distance education reminds me of an angel of fortune as I had more time to study for the teacher recruitment exams." (P29).

3.2 Metaphoric Perceptions of Preservice Music Teachers on the Concept of "Home"

More than half of the participants came up with positive and peaceful metaphors about the concept of home. These metaphors are gathered under the title of "home as a place of peace and happiness". 9 metaphors were expressed under this category and "shelter" was the one to be emphasized the most.. Other metaphors listed under this sub-category were nest, garden, paradise, mother, sea, machine room, friend/mate and therapy. The fact that preservice teachers have mentioned rather positive metaphors regarding the concept of "home" despite the Covid-19 process may be regarded as a pleasing aspect of distance education. For the sake of education quality, students are expected to ensure peace and happiness in their living and learning areas. Some of the opinions expressed by preservice teachers under this category are as follows:

"Home reminds me of a shelter as I feel myself safe here despite this negative process that the world has been through." (P3); "Home reminds me of a nest as I think I can be protected from all evil here." (P14); "Home reminds me of a garden as I smells so pleasant/sweet." (P34); "Home reminds me of heaven as 
it's peaceful and safe." (P21); "Home reminds me of a machine room as I can control everything from here." (P8); Home reminds me of a therapy as it makes me feel quiet and calm." (P73).

Preservice teachers came up with 6 metaphors under the category "home" as a place of punishment and limitation. These metaphors were jail, lattice, dormitory, press, closed box and dollhouse. Although they are few in number, some of the preservice teachers defined "home" as a place of punishment and limitation during the pandemic process. This is something that is not welcomed in distance education, and it may adversely affect students' success. Some of the opinions expressed by prospective teachers under this category are as follows:

"Home reminds me of a jail as I've been feeling like a prisoner for over a year." (P18); “Home reminds me of a lattice as I don't feel myself free at home." (P24); "Home reminds me of dormitory as I feel like I have to live in a place where the rules are set by others." (P58); "Home reminds me of a press as I have nowhere else to run." (P47); "Home reminds me of a doll house as I live wherever they put me at home." (P71).

Preservice teachers suggested2metaphors under the category "home" as a place of enlightenment. These metaphors were school and library. Some of the opinions expressed by preservice music teachers are as follows:

"Home reminds me of school as our place of education has been home for a long time." (P64); "Home reminds me of a library as the place where I study is the same place where I live." (P8).

The metaphors mentioned by participants under the category of "home" as a scary place were nightmare and horror movie. The opinions expressed by the participants with respect to these metaphors are as follows:

"Home reminds me of a nightmare as I can't breathe anymore at home." (P11); "Home reminds me of a horror movie as each passing day I become sour on home." (P74).

Table 3. Metaphors Developed by Preservice Music Teachers on the Concept of "Home"

\begin{tabular}{|c|c|}
\hline Categories & $f$ \\
\hline "Home" as a place of peace and happiness & 43 \\
\hline Shelter & 16 \\
\hline Nest & 9 \\
\hline Garden & 8 \\
\hline Paradise & 4 \\
\hline Mother & 2 \\
\hline Sea & 1 \\
\hline Machine Room & 1 \\
\hline Friend/Mate & 1 \\
\hline Therapy & 1 \\
\hline "Home" as a place of punishment and limits & 24 \\
\hline Jail & 11 \\
\hline Lattice & 8 \\
\hline Dormitory & 2 \\
\hline Press & 1 \\
\hline Closed box & 1 \\
\hline Doll House & 1 \\
\hline "Home" as a place of enlightenment & 8 \\
\hline School & 6 \\
\hline Library & 2 \\
\hline "Home" as a scary place & 5 \\
\hline Nightmare & 4 \\
\hline Horror movie & 1 \\
\hline
\end{tabular}


3.3 Metaphoric Perceptions of Prospective Music Teachers Regarding the Concept of "Graduation"

Table 4. Metaphors Produced by Prospective Music Teachers Regarding the Concept of "Graduation"

\begin{tabular}{|c|c|}
\hline Categories & $f$ \\
\hline Graduation as a positive concept & 40 \\
\hline Beginning & 16 \\
\hline Hope & 7 \\
\hline Achievement & 6 \\
\hline Key & 4 \\
\hline Prize & 2 \\
\hline Flying & 1 \\
\hline Friday & 1 \\
\hline Sleeping & 1 \\
\hline A new house & 1 \\
\hline A white sheet & 1 \\
\hline Graduation as a negative concept & 19 \\
\hline Sorrow & 8 \\
\hline A sad movie & 2 \\
\hline End of a war & 2 \\
\hline Horror movie & 2 \\
\hline Liberation & 1 \\
\hline Good news received at bad times & 1 \\
\hline A sweet dream & 1 \\
\hline A slice of cake I ate when I am sick & 1 \\
\hline The rest of distance education & 1 \\
\hline Graduation as a worrying factor & 16 \\
\hline Obligation & 6 \\
\hline Feeling of emptiness & 5 \\
\hline Question mark & 4 \\
\hline Doomsday & 1 \\
\hline Graduation as a cyclical concept & 5 \\
\hline Retirement & 2 \\
\hline Seasons & 1 \\
\hline First scene of a play & 1 \\
\hline First in a series of books & 1 \\
\hline
\end{tabular}

Nearly half of the preservice music teachers produced positive metaphors about the concept of graduation. These metaphors are gathered under the title "graduation as a positive concept". 10 metaphors were developed under this category and the "Beginning" was the one to be emphasized the most. Other metaphors mentioned under this sub-category were hope, achievement, key, prize, flying, fridat, sleeping, a new house and a white sheet. Some of the opinions expressed by preservice teachers under this category are as follows:

"Graduation reminds me of a beginning as I will be able to achieve what I want to do professionally only after I graduate." (P24); "Graduation reminds me ofhope as I will build my future on those hopes. "(P3);

"Graduation reminds me of achievement as I have come to the end of a very difficult educational journey." (P56); "Graduation reminds me of a key as it will open the door to my career." (P19); "Graduation reminds me of a prize as I will be rewarded for my hard work." (P74); "Graduation reminds me ofFriday as the weekend is about to come." (P1); "Graduation reminds me of a new house as everything about my life is just beginning." (P68); "Graduation reminds me of a white sheet as a brand new process will be waiting for us." (P18).

Preservice teachers came up with 9 metaphors within the category of "graduation as a negative concept". These metaphors are sorrow, sad movie, end of a war, horror movie, liberation, good news received in a bad time, nice dream, slice of cake I ate when I am sick and the rest of distance education. Prospective teachers were expected to 
produce negative metaphors as a result of not being able to experience the graduation they have dreamed of after a long process with distance education. Considering the extraordinary process experienced by preservice teachers, these negative metaphors, which correspond to $20 \%$ of the total number of participants, can still be regarded as optimistic. Some of the opinions expressed by preservice teachers under this category are as follows:

"Graduation reminds me of sorrow as I graduated throughout a hard time." (P7); "Graduation reminds me of a sad movie as the pandemic process has made me feel professionally so sad that I think I will not be able to enjoy my graduation." (P2); "Graduation reminds me of the end of a war as I came out of a great struggle." (P78); "Graduation reminds me of a horror movie as my real life is just beginning." (P59); "Graduation reminds me of liberation as I will get rid of egotist teachers." (P42); "Graduation reminds me of good news received at bad times as I don't have the strength to enjoy it." (P1); "Graduation reminds me of a sweet dream as I know I'll never be able to experience a true one." (P11); "Graduation reminds me of a slice of cake I ate when I am sick as I have no appetite although it is very delicious." (P63); "Graduation reminds me of the rest of distance education as it is symbolic like the rest."

Prospective teachers developed4 metaphors within the category of "graduation as a worrying concept". These metaphors were obligation, feeling of emptiness, question mark and doomsday. Some of the opinions expressed by participants are as follows:

"Graduation reminds me of an obligation as it has to be over soon." (P71); "Graduation reminds me of feeling of emptiness as I can no longer dream due to the pandemic process." (P64); "Graduation reminds me of a question mark as we fall into the void no matter how much we plan." (P21); "Graduation reminds me of doomsday as I worry about my future when I think about my graduation." (P39).

The metaphors mentioned by preservice music teachers under the category of "graduation as a cyclical concept" are retirement, seasons, the first scene of a theater play and the first in a series of books. The opinions expressed by the participants with respect to these metaphors are as follows:

"Graduation reminds me of retirement as I will now devote time to my own profession like other pensioners who can spare time for what they want." (P3); "Graduation reminds me of seasons as one season ends and another begins." (P52); "Graduation reminds me of the first scene of a theater play as the real show is just about to begin." (P29); "Graduation reminds me of the first in a series of books as the most striking part is in the rest of the series." (P47).

\subsection{Metaphoric Perceptions of Preservice Music Teachers on the Concept of "University”}

The metaphors produced by preservice music teachers on the concept of university were analyzed under 5 categories. Among these, the category with the highest number of metaphors is "University" as a hard-to-reach place. Participants came up with8 metaphors under this category. These metaphors are past, dream, homeland, longing, Europe, a cancelled vacation, a journal and Mars. These metaphors reveal that preservice teachers started to perceive university as an inaccessible and hard-to-reach place after the pandemic. Some of the opinions expressed by preservice teachers under this category are as follows:

"University reminds me of the past as I don't feel like I belong there anymore." (P10); "University reminds me of a dream as I can only go there in my dreams." (P27); "University reminds me of homeland as I am longing for it." (P79); "University reminds me of longing as I don't think I'll ever be able to meet again." (P42); "University reminds me of Europe as I can't go to either of them." (P6); "University reminds me of a canceled vacation as I'm actually in my room although I'm enrolled there on paper." (P68); "University reminds me of a journal as it's passed away as the best memories of my life." (P59), “University reminds me of Mars as I can't actually go there even though I have a chance to go." (P21).

Preservice teachers developed 10 metaphors under the category of "university" as a place of development. These are responsibility, step, liberation, land/soil, food, seed, crawling, stage, foundation of a building, value. Some of the opinions expressed by prospective teachers under this category are as follows:

"University reminds me of a responsibility as everything I focus on in my life depends on my going to university." (P54); "University reminds me of a step as that step is very important within the context of what I want to do." (P67); "University reminds me of liberation as it's the only structure where I can make my dreams come true." (P14); "University reminds me of land/soil as the more you sow, the more you reap." (P51); "University reminds me of food as I am hungry for knowledge." (P4); "University reminds me of a seed as I can make flowers bloom and get rewarded as long as endeavor for it." (P36); "University reminds me of crawling as it is the first step to stand on our own feet." (P49); "University 
reminds me of a stage as I have to pass this stage to realize my dreams." (P74); "University reminds me of the foundation of a building as the foundations of academic life is laid here." (P61); "University reminds me of value as I can't think of anything more valuable than education." (P24).

Table 5. Metaphors Developed by Preservice Music Teachers on the Concept of "University"

\begin{tabular}{|c|c|}
\hline Categories & $f$ \\
\hline "University" as a hard-to-reach place & 28 \\
\hline Past & 8 \\
\hline Dream & 7 \\
\hline Homeland & 5 \\
\hline Longing & 4 \\
\hline Europe & 1 \\
\hline A canceled vacation plan & 1 \\
\hline A journal & 1 \\
\hline Mars & 1 \\
\hline "University" as a place of development & 26 \\
\hline Responsibility & 8 \\
\hline Step & 6 \\
\hline Liberation & 3 \\
\hline Land & 2 \\
\hline Food & 2 \\
\hline Seed & 1 \\
\hline Crawling & 1 \\
\hline Stage & 1 \\
\hline Foundation of a building & 1 \\
\hline Value & 1 \\
\hline "University" as a safe place & 16 \\
\hline Nest & 8 \\
\hline Home & 7 \\
\hline Mother & 1 \\
\hline "University" as a place for fun & 6 \\
\hline Social media & 2 \\
\hline Computer game & 1 \\
\hline Technology & 1 \\
\hline Studio & 1 \\
\hline Color and Light & 1 \\
\hline "University" as a place for restriction & 4 \\
\hline Jail & 2 \\
\hline Chaos & 1 \\
\hline World & 1 \\
\hline
\end{tabular}

Preservice teachers have derived 3 metaphors under the category of "university" as a safe place. These are nest, home and mother. Some of the metaphoric opinions expressed by prospective music teachers are as follows:

"University reminds me of a nest as I feel happy when I'm in." (P15); "University reminds me of home as

I feel very peaceful when I am in." (P1); "University reminds me of mother as it is peaceful." (P38).

Preservice music teachers came up with 5 metaphors for the category of "university" as place of fun. These metaphors were social media, computer game, technology, studio and color and Light. The opinions expressed by the participants with respect to these metaphors are as follows:

"University reminds me of social media as I can attain new friends, new knowledge, new skills there." (P3); "University reminds me of a computer game as I can command and direct it as I want." (P71);

"University reminds me of technology as it is constantly evolving." (P18); "University reminds me of a studio as everyone make their own music there, but only one sound comes out." (P73); "University 
reminds me of color and light as I mingle with life and socialize here and find a lot of opportunities about my major." (P61).

Preservice teachers expressed 3 metaphors under the category of "university" as a place for restriction. These metaphors are jail, chaos and world. Samples of metaphoric expressions mentioned by the participants are as follows:

"University reminds me of jail as it limits me socially as it only focuses on education." (P8); "University reminds me of chaos as it is a place of constant turmoil and unrest." (P39); "University reminds me of world as there's life outside of both, but we can't go out." (P15).

\subsection{Metaphoric Perceptions of Preservice Music Teachers on the Concept of "Future"}

Table 6. Metaphors Developed by Preservice Music Teachers on the Concept of "Future"

\begin{tabular}{|c|c|}
\hline Categories & $f$ \\
\hline "Future" as an ambiguous concept & 37 \\
\hline Uncertainty & 8 \\
\hline Obscurity & 7 \\
\hline Darkness & 5 \\
\hline Fortune & 3 \\
\hline Feeling of emptiness & 2 \\
\hline A locked chest & 1 \\
\hline Forest & 1 \\
\hline A dark room & 1 \\
\hline A novel with an unpredictable ending & 1 \\
\hline Air & 1 \\
\hline A dish whose taste I don't know & 1 \\
\hline Question mark & 1 \\
\hline A fruit I've never eaten before & 1 \\
\hline A bottomless pit & 1 \\
\hline A long road & 1 \\
\hline Dice & 1 \\
\hline An empty plate & 1 \\
\hline "Future" as a promising concept & 20 \\
\hline Target & 5 \\
\hline Hope & 5 \\
\hline Dream & 4 \\
\hline Light & 3 \\
\hline Beginning & 2 \\
\hline Dad & 1 \\
\hline "Future" as a desperate concept & 20 \\
\hline Anxiety & 7 \\
\hline Despair & 6 \\
\hline Hopelessness & 4 \\
\hline An extinct star & 1 \\
\hline A thriller movie & 1 \\
\hline Chaos & 1 \\
\hline "Future" as a formative concept & 3 \\
\hline A mirror held to the past & 1 \\
\hline Rope & 1 \\
\hline Black-white & 1 \\
\hline
\end{tabular}


"Future" as an ambiguous concept was the category for which preservice music teachers produced the highest number of metaphors. 17 metaphors mentioned under this category were uncertainty, obscurity, darkness, fortune, feeling of emptiness, a locked chest, forest, a dark room, a novel with an unpredictable ending, air, a dish whose taste I don't know, a question mark, a fruit I've never eaten before, a bottomless pit, a long road, dice and an empty plate. Such uneasy and uncertain metaphors mentioned by preservice teachers about the future is an undesirable situation. Uncertainty of the future, especially with the pandemic, and failure to make long-term plans and decisions affected preservice music teacher, too. Some of the opinions expressed by prospective teachers under this category are as follows:

"Future reminds me of uncertainty as it is nearly impossible to estimate the future in today's conditions." (P7); "Future, in my opinion, is rather obscure as it makes me anxious." (P21); "Future reminds me of darkness as I think I've lost my light." (P24); "Future reminds me of fortune as it is completely unclear indeed whether I will refer to these days as luck or regret." (P36); "Future reminds me of a feeling of emptiness as job opportunities nowadays are nothing but a dream." (P74); "Future reminds me of a locked chest as I can't see what's inside." (P58); "Future reminds me of a forest as I don't know for now whether good or bad things are waiting me in the future." (P1); "Future reminds me of a dark room as I can't see what's inside." (P35); "Future reminds me of a novel with an unpredictable ending as I don't know the end until I read it." (P18); "Future reminds me of air as I know it exists, but I can't see it." (P47); "Future reminds me of a dish whose taste I don't know; maybe something I will not like at all is waiting for me, I don't know." (P40); "Future reminds me of a question mark as it is full of uncertainty." (P69); "Future reminds me of a fruit I've never eaten before as I'm hesitant." (P3); "Future reminds me of a bottomless pit as anything is possible nowadays." (P41); "Future reminds me of a long road as it is a journey whose ending will be unknown." (P11); "Future reminds me of a dice as it is not clear what will happen no matter what I have planned." (P60); "Future reminds me of an empty plate as it is not clear in today's conditions what will be written on that plate at any moment." (P14).

Preservice teachers came up with6 metaphors within the category of "future as a promising concept". These metaphors are target, hope, dream, light, beginning and dad. Some of the metaphors mentioned by prospective music teachers under this category are as follows:

"Future reminds me of a target as what I aim for lays in the future." (P63); "Future reminds me of hope as I hope to achieve success in the future and have a very good life." (P80); "Future reminds me of a dream as I cannot succeed without dreaming." (P71); "Future reminds me of light as I get rid of the darkness by recalling my dreams and thoughts about the future whenever I fall into darkness." (P78); "Future reminds me of a beginning as every new day is a start for the future." (P27); "Future reminds me of my Dad as he always wants me to get better, but even if I can't, he doesn't turn his back on me and just keeps flowing." (P51).

Preservice teachers proposed 6 metaphors within the category of "future" as a desperate concept". These metaphors are anxiety, despair, hopelessness, an extinct star, a thriller movie and chaos. Some of the opinions expressed by prospective music teachers are as follows:

"Future reminds me of a feeling of anxiety as we shall always run into trouble." (P68); "Future reminds me of a feeling of despair as I gave up as lost." (P15); "Future reminds me of a feeling of hopelessness as job opportunities nowadays are rather limited.” (P30); “Future reminds me of an extinct star as I can't see a light about myself at the end of the road." (P57); "Future reminds me of a thriller movie as every moment is full of anxiety." (P33); "Future reminds me of chaos as it is completely uncertain and hopeless. " (P43).

The metaphors mentioned by prospective music teachers under the category of "Future" as a formative concept were a mirror held to the past, rope and black-white. The opinions expressed by the participants with respect to these metaphors are as follows:

"Future reminds me of a mirror held to the past as I can build a better future only by learning lessons from the past." (P22); "Future reminds me of a piece of rope as it's up to me to shape it, even if it's a flat piece of rope." (P53); "Future reminds me of black-white as either the future will shape me up or I will shape it." (P61). 


\section{Conclusion and Discussion}

A total of 80 prospective music teachers, who are in the final year of their undergraduate education at the Department of Music Education, participated in this research, aim of which is to identify post Covid-19 metaphoric perceptions of preservice music teachers on various concepts. For the purpose of this research, which focused on the metaphoric perceptions of concepts such as "Distance Education, Home, Graduation, University and Future", participants came up with a total of 133 different metaphors, 26 of which were about distance education, 19 were about home, 27 about graduation, 29 about university and 32 about the concept of the future.

The metaphors produced by prospective teachers regarding distance education exhibit a rather negative outlook due to the Covid-19 pandemic, which has been going on for about 16 months. Air and torture were the metaphors used by the largest amount of participants while completing the sentence "distance education reminds me of ...because...".The metaphor of "Air" mentioned by prospective teachers represents the idea that there is an ongoing education, but this education is not concrete and does not really reach its goal. The metaphor "Torture" reflects the idea that prospective teachers do not believe in distance education. However, they are required to continue their education and that they consider it as torture. The number of preservice teachers who produced positive metaphors regarding distance education is quite low. "Key" and "game" were the most frequently emphasized positive metaphors under this title. "Key" as a metaphor represents that distance education guides prospective teachers, while "game" represents that it is actually a concept of fun when the rules are learned.

Metaphoric studies on distance education are divided into two groups as study group students and academicians. The studies where the study group consists of students are divided into two: (1) as the metaphoric perceptions of primary and secondary school students towards distance education (Akpolat, 2021; Güngörmez, 2020; Bozkurt, 2020a) and (2) metaphoric perceptions of students studying at higher education institutions towards distance education (Demirbilek, 2021; Atik, 2020; Y1lmaz and Güven, 2015; Çivril, Arugaslan, \& Özkara, 2017). While positive metaphors such as time and space comfort, access to technology, being fun and comfortable were proposed within the scope of these studies, negative metaphors were also produced such as extracurricular learning, lack of communication, inadequacy of content, infrastructure problems, lack of interaction and artificiality. Regardless of the level of education, students' perspectives on distance education have been very close and similar in all studies. All the studies analyzed in literature review support each other in terms of their results.

Quite a high number of prospective teachers produced positive metaphors regarding the concept of "home", which is the second concept investigated. 9 out of 19 metaphors expressed in this category fall under the category of "home" as a place of peace and happiness. Throughout the process of distance education, prospective teachers have carried home almost all their lives. Throughout this process, their home have been areas of rest, work and socialization at the same time. Such a positive approach by the participants on the concept can be explained by the increasing significance of the concept of home during the pandemic, while they had already been away from their families and homes until then. $20 \%$ of the prospective teachers attributed the metaphor of shelter to the concept of home. Nest and garden are also metaphors that were mentioned with a similar percentage. Jail was the most frequently mentioned metaphor with unfavorable/negative connotation, whereas the cage was the second one in this regard. Such judgments are anticipated, considering that prospective teachers have remained in lock-down, in front of a computer screen for 16 months. Davies (2014), in the metaphoric study on the concept of home, concluded that home may be referred to as either public and private, symbolic and material, nostalgic and agnostic, personal and political, psychological and spatial, individual and social, isolated and ecological.

27 different metaphors classified under 4main categories were found while analyzing the metaphoric perceptions of participants on the concept of "graduation". Majority of the preservice music teachers expressed positive metaphors on the concept of graduation. "Beginning" has been the most frequently mentioned metaphor and followed by "sorrow", which is a rather negative concept. Preservice teachers who expressed their metaphoric perception with the concept of "beginning" justified their opinion as they believed that real life will begin after graduation and that graduation is the beginning of the main objectives they want to achieve. The concept "sorrow" is mentioned on the grounds that they had to celebrate their graduation on digital platforms due to extraordinary pandemic outbreak rather than experiencing a real, physical one. Keleș, Doğan and Kaya (2019) examined metaphoric perceptions of undergraduate students on the concept of "graduation" and revealed that more than half of them attributed favorable/positive metaphors to the concept of "graduation"; such as to be acquitted, achievement, a baby's first steps, baby's walk, baby, a wise man, a doctor, awareness, entrepreneurship, sun, to be relieved, weekend, to realize the dreams, beginning of dreams, to turn over a new leaf, to approach the targets, a cargo delivery, liberation, last step of the stairs, pleasure, freedom, wealth, excellence, to promote, responsibility, a white sheet, advancing to a bicycle 
from a tri-cycle and to be reborn. This conclusion is in in line with other studies conducted with bachelor's degree students on the concept of "graduation" in terms of positive metaphors produced.

29 different metaphors classified under 5 categories were reached while analyzing the metaphoric perceptions of participants on the concept of "university". Due to the pandemic process, participants declared that they have perceived the university as a hard-to-reach place hence they have attributed metaphors that recalled longing. They stated that the university concept remained in the good old days, they have long been dreaming about their university and that they have missed university just like homeland. "University" as a place of development has been the second category following "a hard-to-reach place" for which high number of metaphors have been mentioned. Metaphors such as responsibility and steps were the ones to be mentioned the most. The metaphors emphasizing the positive aspects of the university were found as a result of the metaphoric studies carried out on the concept of "university" (Korkmaz and Bağçeci, 2013; Uğurlu, 2018; Demirtaş and Çoban, 2014). Positive metaphors such as the union of differences and similarities, place of change and development, production center, science center, freedom, future, cultural diversity are some of the common results obtained in these studies. The most prominent metaphor about the concept of university has been "jail".

The concept of "future" has been the latest concept on which the ideas of prospective teachers were asked. The views of the prospective music teachers on "future" concept in the new order occurring after Covid-19 pandemic are also questioned. The highest number of metaphors mentioned by the participants pertained to the concept of "future". Prospective teachers have produced 32 metaphors under 4 different categories. Majority of the participants responded that they perceive future as an ambiguous concept whereas the number of people who perceive future as a promising and desperate concept were somewhat equal. Main metaphors produced regarding the concept of "future" are ambiguity, obscurity and darkness. Phenomena such as the suspension/postponement of teacher recruitment exams during the pandemic outbreak and suspension of many institutions to recruit post graduate students and extra personnel caused "future" to become a negative/ambiguous concept for prospective teachers. A preservice teacher who does not feel safe is not expected to be confident about the future. Therefore, producing ambiguous and hopeless metaphors for the purpose of the research is only natural, due to the pandemic. Yam, Çetinkaya and Kurnaz (2018), in their metaphoric study on the concept of future, concluded that students are confident about the future, but still an unknown is awaiting them. Uncertainty about the future is the common view of the participants although this was a study carried out before the pandemic outbreak. Topgül (2017), in his study investigating university students' metaphoric perceptions on the concept of future, recruitment and profession, concluded that majority of the students mentioned promising metaphors however the number of metaphors indicating ambiguity are quite high. Çelik and Yarım (2019), in their study investigating university students' metaphoric perceptions on the concept of university, rector and future concluded that students have produced pessimistic, hopeless and anxious metaphors about the future.

\section{Suggestions}

Metaphorical studies allow individuals to express themselves more easily and to attribute a wider number of meanings to a single concept. Conducting such phenomenological studies in every field, especially during periods such as pandemics that significantly affect countries and cause sharp changes in society, will enable the collection of students' views on different concepts. Conducting metaphoric studies on concepts such as university, home and distance education after the Covid-19 pandemic will enable to look at the process from the other side. In addition, it is suggested to conduct further metaphoric studies on other concepts that may have been affected by the Covid-19 pandemic in order to evaluate the education system within the context of this process. Conducting a new metaphoric study on the same concepts with prospective teachers soon after the pandemic outbreak ends and the education system returns to normal will clearly confirm whether the desperate and negative statements revealed in the findings of this research are due to the Covid-19 pandemic.

\section{References}

Akça, O., M., Şen, Ç., \& Kurtaslan, Z. (2019). Determination of science and art centers music field's students perception of music concept: a study of methapor analysis. AfyonkarahisarUniversity Amader, 10, 123-145. https://doi.org/ 10.36442/amader.20191055041

Akpolat, T. (2021). Investigation of middle school students' metaphoric perceptions regarding distance education. Ankara University Journal of Faculty of Educational Sciences, 54(2), 497-522. 
https://doi.org/10.30964/auebfd.822101

Atik, A. D. (2020). Pre-service science teachers' perception of distance dducation: A metaphor analysis. International Journal of Educational Researchers, 3(2), 148-170.

Babacan, E. (2014). AGSL students' perceptions of the concept of music: metaphor analysis. Journal of Education and Training Research, 3(1), 124-132.

Bond, M. (2020). Schools and emergency remote education during the COVID-19 pandemic: A living rapid systematic review. Asian Journal of Distance Education, 15(2), 191-247.

Bozkurt, A. (2020a). Images and perceptions of primary school students towards distance education during coronavirus (covid-19) pandemic: a metaphor analysis. Uşak University Journal of Educational Research, 6(2), $1-23$.

Bozkurt, A. (2020b). The coronavirus (Covid-19) pandemic process and evaluations on education in the postpandemic world: New normal and new education paradigm. Journal of Open Education Applications and Research, 6(3), 112-142.

Büyüköztürk, Ş., Çakmak, E. K., Akgün, Ö. E., Karadeniz, Ş., \& Demirel, F. (2010). Bilimselaraştırma yöntemleri (6th ed.). Ankara: PegemAkademi.

Çelik, S., \& Yarım, M. A. (2019). Investigation of methodorical perceptions of university students on university, rector and future concepts. Turkish Journal of Educational Studies, 6(2), 31-50.

Chan, E. A., \& Nyback, M. H. (2015). A virtual caravan-A metaphor for home-internationalization throughsocial media: A qualitative content analysis. Nurse Education Today, 35(6), 828-832. https://doi.org/10.1016/j.nedt.2015.01.024

Çivril, H., Aruğaslan, E., \& Özkara, B. Ö. (2017). Distance education perceptions of distance education students: a metaphor analysis. Educational Technology Theory and Practice, 8(1), 39-59. https://doi.org/10.17943/etku.310168

Davies, M. (2014). Home and state: reflections on metaphor and practice. Griffith Law Review, 23(2), 153-175. https://doi.org/10.1080/10383441.2014.962447

Demirbilek, N. (2021). Metaphoric perceptions of university students on distance education. International Journal of Educational Research, 12(1), 1-15. https://doi.org/ 10.19160/ijer.786303

Demirtaş, H., \& Çoban, D. (2014). Metaphors of university students regarding the concepts of university and faculty (Inonu University example). Ondokuz Journal of May University Faculty of Education, 33(1), 113-143. https://doi.org/ 10.7822/egt203

Düzgören, H., \& Gerekten, S. E. (2017). The perceptions of Anatolian high school students about the concept of 'music lesson'. Online Journal of Music Sciences, 2(3), 86-117.

Erbaş, H. (1992). Phenomenology in Sociology. Research Journal of Ankara University, Faculty of Language, History and Geography, Department of Philosophy, 14.

Eren, B. (2018). Metaphorical perceptions of special education teacher candidates about the concept of "music". Turkish Studies Educational Sciences, 13(19), 697-716.

Girgin, D. (2019). Metaphorical perceptions of music teacher candidates towards instrument education. Journal of Qualitative Research in Education, 7(1), 161-175.

Güngörmez, H. G. (2020). Investigation of the perceptions of the secondary school students who received distance education regarding distance science education through metaphors during the Covid-19 pandemic process. EJERCongress 2020 Abstracts, Anı Publishing.

Keleş, Y., Doğan, S., \& Kaya, M. (2019). Graduation metaphors of students who receive tourism education at the undergraduate level: Example of Ondokuz Mayls University. 20th National and 4th International Tourism Congress Proceedings. Anadolu University, Eskişehir.

Kılıç, D. B. Ç. (2017a). Pre-service music teachers' metaphors for the concept of teacher. Kastamonu Journal of Education, 25(3), 1099-1118.

Kılıç, D. B. Ç. (2017b). Pre-service music teachers' metaphorical perceptions of the concept of a music teaching program. Journal of Education and Learning, 6(3), 273-286. 
Koca, Ş. (2012). The pre-school teacher candidates' metaphorical thinking about the concept of music learning. Procedia - Social and Behavioral Sciences, 47, 1485-1489.

Kocabiyık, O. O. (2015). Phenomenology and grounded theory: a comparison in terms of some features. Journal of Trakya University Education Faculty, 6(1), 55-66.

Korkmaz, F., \& Bağçeci, B. (2013). An examination of high school students' metaphoric perceptions on the concept of "university". Bartın University Journal of Faculty of Education, 2(1), 187-204.

Miles, M. B., \& Huberman, A. M. (1994). Qualitative Data Analysis: An Expanded Sourcebook (2nd ed.). Thousand Oaks, CA: Sage.

Özaydın, N. (2019). Metaphors of music teacher candidates related to the concept of "voice". International Journal of Society Researches, 9(13), 332-358. https://doi.org/10.26466/opus.595393

Rahiem, M. D. H. (2020). The emergency remote learning experience of university students in indonesia amidst the Covid-19 crisis. International Journal of Learning, Teaching and Educational Research, 19(6), 1-26. https://doi.org/10.26803/ijlter.19.6.1

Sözbir, S. A., \& Çakmak, Ö. Ç. (2016). Metaphorical perceptions of preschool teacher candidates about the concept of "music". The Journal of Academic Social Science Studies, 42, 269-282.

TDK (2021). TürkDilKurumu. Retrieved from https://sozluk.gov.tr/ (ErişimTarihi: 12.07.2021)

Tez, İ., \& Uygun, M. A. (2016). A metaphorical analysis of middle-school students' perceptions on music lesson and music teacher. Kalem Journal of Education and Human Sciences, 6(2), 415-453.

Topgül, S. (2017). Metaphoric perceptions of labor economics and industrial relation students on the future, employment and occupation. Journal of Labour Relations, 8(1), 100-117.

Toquero, C. M. (2020). Emergency remote education experiment amid COVID-19 pandemic in learning institutions in the Philippines. International Journal of Educational Research and Innovation, 15, 162-176. https://doi.org/10.46661/ijeri.5113

Tunç, G. (2014). Ahmet Haşim's poem "Staircase" in the context of conceptual metaphor and poetic metaphor relationship. Mehmet AkifErsoy University Journal of Social Sciences Institute, 6(11), 186-191.

Turgut, Y. (2012). Bilimselaraştırmayöntemleri. Chapter VIII. Ed: Prof. Dr. Abdurrahman Tanrı̈ğen (3rd ed.) Ankara: Anı Publishing.

Turhan, M., \& Yaraş, Z. (2013). Teachers' and students' metaphorical perceptions related to teacher, discipline, principal, classroom rules, reward and punishment. Firat University Journal of Social Science, 23(1), 129-145.

Uğurlu, Z. (2018). The metaphors teacher candidates produced concerning university notion. Journal of Contemporary Administrative Science, 1(5), 82-97.

Umuzdaş, S., \& Umuzdaş, M. S. (2013). Determining the perceptions of primary school teaching students about the music lesson through metaphor. International Journal of Human Sciences, 10(1), 719-729.

Uygun, M. A. (2010). Examination of pre-service teachers' perceptions of traditional music genres through metaphors. Afyon Kocatepe University Journal of Academic Music Research, 1(1), 1- 16.

Yam, Z., Çetinkaya, H., \& Kurnaz, A. (2018). A metaphorical examination of gifted students' perception of "future" concept. Journal of National Education, Education of the Gifted and Talented Special Issue, 47(1), 67-90.

Yıldırım, A., \& Şimşek, H. (2008). Sosyal Bilimlerde Nitel Araştırma Yöntemleri (6th ed.) Ankara: Seçkin Publishing.

Yılmaz, G. K., \& Güven, B. (2015). Determining the teacher candidates' perceptions on distance education by metaphors. Turkish Journal of Computer and Mathematics Education, 6(2), 299-322. https://doi.org/10.16949/turcomat.75936

Zamora-Antuñano, M. A., Rodríguez-Reséndiz, J., Rodriguez Segura, L., Cruz Pérez, M. Á., Altamirano Corro, J. A., Paredes-Garcia, W. J., \& Rodríguez-Reséndiz, H. (2021). Analysis of Emergency Remote Education in COVID-19 Crisis Focused on the Perception of the Teachers. Sustainability, 13(7), 1-19. https://doi.org/10.3390/su13073820 


\section{Copyrights}

Copyright for this article is retained by the author(s), with first publication rights granted to the journal.

This is an open-access article distributed under the terms and conditions of the Creative Commons Attribution license (http://creativecommons.org/licenses/by/4.0/). 